\title{
Who Made Our Clothes Under Which Conditions? A Call for Ethical Standards in the Fashion Supply Chain
}

\author{
Anna Kathrin Sebald* and Frank Jacob \\ Department of Marketing, ESCP Europe Business School Berlin, Germany \\ *Corresponding author: Anna Kathrin Sebald, Department of Marketing, ESCP Europe Business School Berlin, Heubnerweg 8-10, D-14059 Berlin, \\ Germany
}

Submission: 望 February 09, 2018; Published: 眥 February 16, 2018

\begin{abstract}
Despite the initiatives of numerous nongovernmental agencies worldwide, getting governments and multinational corporations to implement more ethical standards in fashion supply chains remains challenging. The human rights abuses and worker exploitation that have already resulted in disastrous factory accidents and loss of lives continue to occur in the fashion industry. This opinion essay critically discusses the prevailing fashion supply chain conflict between ethical demands and commercial requirements and presents a call for ethical standards in fashion. It addresses the internationalization of the fashion supply chain, undesirable side effects of retail buying practices (e.g., ignoring environmental issues) and appropriate countermeasures for recovery. In addition, it illustrates that the implementation of strategic corporate social responsibility can result in brand protection and competitive business advantages.
\end{abstract}

Keywords: Fast fashion; Fashion supply chain management; CSR implementation; Ethical sourcing

\section{Introduction}

Due to increasing globalization and heightened competition, today's fashion industry has become a highly volatile, segmented and demanding market characterized by cost pressure, labyrinthine global sourcing networks and short lead times. For example, in the context of supply chain management (SCM), fast fashion pioneers Zara and top shop contributed to a significant change in the late 1990s: They democratized the overall fashion marketplace by making catwalk looks affordable and available to the mainstream consumer. Moreover, not only fast fashion retailers benefit from offshore sourcing; such luxury brands as Burberry and Armani outsource noncore activities to the developing world as well [1]. Given these globally dispersed supply chains, 'the fashion industry has become a focal point for debates on the social responsibility of business' [2]. The mass media and public blame fashion retailers for turning a blind eye to child labour, corruption and human rights abuses [3], and the call for ethical standards has become louder. Underlying the desired transformation of the fashion industry is the question: Who made our clothes under which conditions?

\section{Global fashion supply chain management}

Particularly within the manufacturing sector of the fashion industry, SCM constitutes a key strategic success factor. It represents a sound basis for achieving efficiency and cost gains, and most important, it ensures competitive abilities. Consequently, the fashion industry has increasingly shifted its primary focus away from competition between companies and towards competition between supply chains $[4,5]$. In this context, offshore outsourcing to suppliers in less developed countries has become a common feature and a crucial strategic pillar for business growth. The key drivers for this shift to global sourcing can be summarized as follows: increased global competition, downward price pressure, time compression and, most important, the labour- intensive nature of the garment production [2]. The liberalization and expansion of free trade in the garment industry have further facilitated supply chain flexibility and internationalization strategies [6].

\section{CSR implementation in fashion}

The entrance into foreign markets, however, does not exempt fashion retailers from legal and ethical responsibility towards stakeholders and the social environment. Indeed, it makes an active corporate social responsibility (CSR) approach in the fashion supply chain inevitable. In accordance with the World Business Council for Sustainable Development (WBCSD), CSR is the continuing commitment by business to behave ethically and contribute to economic development while improving the quality of life of the workforce and their families as well as of the local community and society at large' [7]. In fashion, power imbalances between 
suppliers and retailers as well as lead time and commercial cost pressures challenge CSR implementation in global fashion SCM [8]. An inherent conflict exists between retailers' commercial buying practices and their suppliers' ability to comply with ethical standards [9]. Nevertheless, now more than ever retailers need to assume responsibility for the labour practices of their suppliers, intermediaries and third-party logistics providers [4]. A problem, however, is that fashion retailers typically do not have complete control and transparency over their suppliers' actions. Their mutual relationship is largely based on trust. To improve collaboration, thus, it is worth investigating the traditional buyer-supplier relationships in the fashion industry more closely.

\section{Traditional fashion buyer supplier relationships}

Fashion retail sectors differ regarding the nature of the product, the degree of outsourcing and the design of the supply chain; thus, various trading relationships with suppliers have emerged [10]. Historically, the vertical integration model is more widespread in the luxury fashion sector, as leading luxury brands tend to internalize production functions to maintain exclusivity and merchandise quality [11]. For instance, in 2012 the French couture house Chanel bought its Scottish cashmere supplier [12]. However, several exceptions to the rule also exist, such as Prada, which outsourced nearly $20 \%$ of its collection to China in 2011 [13]. In contrast, vertical integration is rare among mid-market and fast fashion retailers, who use outsourcing as essential cost reduction measure [14].

Traditionally, buyer-supplier relationships in the fashion industry are short term, buyer driven or even adversarial [5]. Being exposed to price reductions and increased payment terms while simultaneously being expected to meet changing customer demands and to offer low cost quality products puts manufacturers under intense time and cost pressure [8].

\section{From power imbalances towards strategic supplier partnerships}

From the perspective of Porter's five forces, retailers can become more competitive by leveraging their position in the supply network. As Porter $[15,16]$ explains, supplier power, or the bargaining power of suppliers, shapes the competitiveness of an industry and, therefore, its attractiveness in terms of profitability. With regard to CSR, however, existing power imbalances must be transformed into strategic partnerships. Industrial upgrading, increased collaboration and information sharing can drive such redistribution of power in the supply chain further [17]. Fostering long-term relationships with fewer suppliers can maximize supply chain responsiveness, reduce costs and improve business performance without compromising worker welfare and CSR principles. Beyond that, retailers have an advocacy role to play in leveraging their buyer power to pressure governments of developing nations to increase industrial standards. Furthermore, encouraging and supporting their manufacturers to adopt CSR standards could prove transformative [2].

\section{The high cost of fast fashion}

Beyond power imbalances in buyer-supplier relationships, challenges to CSR implementation in fashion can arise from seasonality, price competition and short product life cycles. In particular, cost and lead time pressures in the fast fashion sector highlight the time- sensitive nature of apparel production. According to Barnes \& Lea-Greenwood [5], 'fast fashion is a business strategy which aims to reduce the processes involved in the buying cycle and lead times for getting new fashion products into store' on a frequent basis. The secret of Spanish clothing retailer Zara's success is based on this manufacturing philosophy [18]. Zara demonstrates that organizational responsiveness and agility can constitute a major source of competitive advantage in an industry in which timing [19] and survival of the cheapest [20] are key. In 2013, however, Zara was accused of unlicensed apparel production through Bolivian labourers in Argentina [21]. This incident clearly proves that such a business strategy driven by trend- obsessed consumers comes at a high cost to suppliers. Retailers should therefore review their buying practices [22]. For instance, the implementation of realistic delivery schedules and the avoidance of last-minute orders might further relieve pressure on suppliers and limit overtime work. Even slight lead time extensions of one day could make a measurable difference towards an acceptable and safer workplace culture. Such measures would lead to suppliers being gradually considered as success-determining company resources instead of mere cost factors [22].

\section{The rana plaza factory collapse}

This strategic change would be an important initial step to address the main social issues of CSR, such as poor working conditions, low wages and weak regulatory compliance. Where the race to the bottom on fast fashion can lead has become painfully apparent with the Rana Plaza factory collapse [20,23]. In 2013, approximately 1, 2004 labourers died in the Bangladeshi factory collapse, making the world aware of the disastrous consequences of today's fast fashion supply chains [24]. Then, as now, child labour, human rights abuse and worker exploitation were omnipresent in sweatshops supplying Western brands and retailers such as Primark, Benetton and Mango [25]. Instead of denying their responsibility for subhuman working conditions, retailers should use factory tragedies like this as an impetus to implement CSR in their global supply network. No longer must outsourcing be misused to evade moral responsibility by applying local standards to business operations [26]. In the future, legally binding agreements or industry alliances are thus inevitable to achieve a higher minimum working age, greater standards for safety inspections and collective bargaining arrangements.

\section{Low wage levels and weak regulatory compliance}

The low wage level in garment-producing countries represents a further negative symptom of global production outsourcing. According to Article 23(3) of the Universal Declaration of Human Rights, a living wage is a human right [27]. In accordance with the Worker Rights Consortium, a slight trade price increase of less 
than 10 cents per garment would be sufficient to enhance safety standards [25]. This figure illustrates that implementing CSR standards is not an impossible or necessarily a business- damaging task. Fashion retailers can afford to provide fair pay to make it financially feasible for manufacturers to increase both factory safety standards and wages $[28,29]$.

Concerning fire and building safety, weak regulatory compliance remains another serious problem in emerging markets, however. In particular, bribery and collusion between safety auditors and factory owners jeopardise workers' lives. To foster and emphasize the importance of CSR, global apparel companies should collaborate proactively with governments and suppliers [30]. This will require national governments to enact appropriate laws to assure compliance with international and local labour standards and to promote a corruption-free business environment [31]. Nongovernmental organizations can make an important contribution to this slow gradual process of CSR implementation [32].

\section{Towards ethical sourcing and consumerism in fashion}

Given the variety of obstacles outlined previously, implementing CSR principles in the fashion supply chain seems challenging. However, role models for a successful implementation of CSR practices already exist. Among existing garment locations, Sri Lanka stands out from lower labour manufacturing countries such as China, India, Bangladesh or Cambodia, even though it cannot compete on cheap, fast fashion products. Instead, Sri Lanka has achieved an ethical credential and point of differentiation because it has become known for its decent labour standards and eco-friendly apparel manufacturing [2]. At the company level, Timberland, an American global player in outdoor lifestyle clothing and footwear, constitutes a prime example of how CSR can serve as a marketing tool to improve social legitimacy, customer-company identification and competitive capabilities [33,34]. At Timberland, more than 300 factories in 30 countries are supported by the Groups' Regional Supplier Sustainability Teams to generate worker empowerment and to promote non-discriminatory, safe workplaces. The teams closely monitor suppliers to ensure conformity with the corporation's Global Compliance Principles [35]. In the interest of transparency, key performance indicators, results from factory audits and a factory list, including the supplier's name, country and address, are updated quarterly [36]. To create sustainable living environments, Timberland also cooperates with local communities and organizations by initiating water, education and microfinance projects [37]. By proactively incorporating CSR in its entire value chain and stakeholder relationships, Timberland has been positioned at the vanguard of ethical sourcing.

\section{A call for ethical standards in fashion}

The key challenges and concerns in the fashion supply chain range from commercial cost and lead time pressures to subhuman working conditions and weak regulatory compliance. From a business perspective, fashion retailers consider outsourcing manufacturing to less- developed markets a strategic choice because it enhances cost reduction, efficiency in the supply chain and shareholder returns [9]. But simply following Milton Friedman's dictum 'The business of business is business' [38] at the cost of labourers is short-sighted and interferes with an active CSR approach. Instead of turning a blind eye to the social impact of their operations, fashion corporations must balance ethical issues and strategic commercial interests. Timberland's successful business model demonstrates that CSR and profitability are not necessarily conflicting and promotes ethical consumerism in fashion. More global clothing players should take it as example to act as catalysts for changing the culture of fashion. This process will be lengthy and gradual, but the increasing popularity of socially and environmentally sound fashion gives grounds for hope. Even though the labour-intensive garment production can be outsourced, the retailer's responsibility cannot be passed down the supply chain. Consumers, together with nongovernmental organizations and governments, must make this ethical call to action un mistakably loud, giving a voice to those who made our clothes.

\section{References}

1. Tsui E (2012) The luxury that dare not speak its name. The Financial Times.

2. Perry P, Fernie J, Wood S (2014) The international fashion supply chain and corporate social responsibility. In: Fernie J, Sparks L (Eds.), Logistics and retail management: Emerging issues and challenges in the retail supply chain, $\left(4^{\text {th }}\right.$ edn), Kogan Page, London, UK.

3. Khan ZR, Rodrigues G, Balasubramanian S (2017) Ethical consumerism and apparel industry towards a new factor model. World Journal of Social Sciences 7(1): 89-104.

4. Andersen M, Skjoett-Larsen T (2009) Corporate social responsibility in global supply chains. Supply chain management: an international journal 14(2): 75-86.

5. Barnes L, Lea GG (2006) Fast fashioning the supply chain: shaping the research agenda. Journal of Fashion Marketing and Management: An International Journal 10(3): 259-271.

6. Hale A (2002) Trade liberalization in the garment industry: Who is really benefiting? Development in Practice 12(1): 33-44.

7. WBCSD (1999) Corporate social responsibility: meeting changing expectations. WBCSD Publications, Geneva, Europe.

8. Schwartz B, Tilling K (2009) 'ISO-lating' corporate social responsibility in the organizational context: A dissenting interpretation of ISO 26000. Corporate Social Responsibility and Environmental Management 16(5): 289-299.

9. Acona (2004) Buying your way into trouble? The challenge of responsible supply chain management. Business \& Human Rights Resources centre.

10. Fisher M (1997) Which is the right supply chain for your product?. Harvard Business Review 75(2): 105-117.

11. Brun A, Caniato F, Caridi M, Castelli C, Miragliotta G, et al. (2008) Logistics and supply chain management in luxury fashion retail: empirical investigation of Italian firms. International Journal of Production Economics 114(2): 554-570.

12. Chesters L (2012) Chanel wraps up in Scottish cashmere. The Independent.

13. Sanderson R (2013) Manufacturing: consumers push big luxury names to account for supply chains. Financial Times.

14. Perry P, Wood S, Fernie J (2015) Corporate social responsibility in garment sourcing networks: Factory management perspectives on ethical trade in Sri Lanka. Journal of Business Ethics 130(3): 737-752. 
15. Porter ME (2008) The five competitive forces that shape strategy. Harv Bus Rev 86(1): 25-40.

16. Porter ME (1979) How competitive forces shape strategy. Harvard Business Review 59(2): 137-145.

17. Gereffi G (1999) International trade and industrial upgrading in the apparel commodity chain. Journal of International Economics 48(1): 37-70.

18. Berfield S, Baigorri M (2013) Zara's fast-fashion edge. Bloomberg Business week.

19. Daly M (2006) Buyer behaviour for fast fashion. Journal of Fashion Marketing and Management: An International Journal 10(3): 329-344. Ajaltouni et al. (2014) Tailored wages UK: Are the big brands paying the people who make the people who make our clothes enough to live on?. Labour Behind the Label Ltd.

21. Osborne L (2013) High-street fashion store zara accused of using slave labour at factories in argentina. Daily Mail.

22. Lund TP, Lindgreen A (2013) Corporate social responsibility in global value chains: Where are we now and where are we going? Journal of Business Ethics 123(1): 11-22.

23. Lee MSW, Seifert M, Cherrier H (2017) Anti-consumption and governance in the global fashion industry: Transparency is key. In: Hira A, Benson RM (Eds.), Governing corporate social responsibility in the apparel industry after Rana Plaza. Palgrave Macmillan, New York, USA.

24. Gifford J, Ansett J (2014) 10 things that have changed since the Bangladesh factory collapse. The Guardian.

25. Corporate Crime Reporter (2013) Put an end to this parade of horror.
20. McMullen A, Christa Luginbühl, Kate Nolan, Carole Crabbé, Nayla

26. Polonsky M, Jevons C (2009) Global branding and strategic CSR: An overview of three types of complexity. International Marketing Review 26(3): 327-347.

27. United Nations (2014) The universal declaration of human rights.

28. Minney S (2008) Fair trade is a slow process. The Guardian.

29. Quadir S (2014) Rising wages squeeze bangladesh garment makers as factories await upgrades. Reuters.

30. Berg A, Hedrich S (2014) What's next in apparel sourcing?. McKinsey \& Company.

31. Transparency International (2014) Call on clothing companies to tackle corruption, factory safety.

32. O'Rourke D (2013) Fashion firms must pay the price of safety in Bangladesh. The Guardian.

33. Ghauri P, Cateora P (2010) International marketing, ( $3^{\text {rd }}$ edn), McGrawHill Education, Berkshire, UK.

34. Homburg C, Stierl M, Bornemann T (2013) Corporate social responsibility in business-to- business markets: How organizational customers account for supplier corporate social responsibility engagement. Journal of Marketing 77(6): 54-72.

35. Timberland (2018a) Timberland upholds the rights of factory workers.

36. Timberland (2017) CSR Full Report Q3 2017.

37. Timberland (2018b) Timberland Responsibility.

38. Dicken P (2011) Global shift: Mapping the changing contours of the world economy, (6 $6^{\text {th }}$ edn), The Guilford Press, New York, USA.

Creative Commons Attribution 4.0

International License

For possible submission use the below is the URL

\section{Your subsequent submission with Crimson Publishers will attain the below benefits}

- High-level peer review and editorial services

- Freely accessible online immediately upon publication

- Authors retain the copyright to their work

- Licensing it under a Creative Commons license

- Visibility through different online platforms

- Global attainment for your research

- Article availability in different formats (Pdf, E-pub, Full Text)

- Endless customer service

- Reasonable Membership services

- Reprints availability upon request

- One step article tracking system 